János Kundrák, István Deszpoth, Viktor Molnár, Miskolc, Hungary

\title{
INCREASING PRODUCTIVITY OF COMBINED PROCEDURE BY REDUCING GRINDING ALLOWANCE
}

\begin{abstract}
Experiments were carried out to determine the minimal extent of acceptable grinding allowance on case-hardened workpieces machined by combined procedure. The extent of acceptable or unacceptable allowance was determined by a "painting" method. After bore grinding tests for $2 D$ roughness, roundness and $3 D$ topography measurement were carried out. It was found that a $0.03 \mathrm{~mm}$ allowance in the bores of gearbox wheels of cars is satisfactory and also necessary to obtain the required level of topography when combined machining was applied and when no white layer formed in the turning procedure. This is a significant finding, because the usual allowances of $0.05 \mathrm{~mm}$ or higher (in many cases significantly higher) can be decreased to $0.33 \mathrm{~mm}$ and the machining time of bore grinding can be reduced in proportion to this extent.
\end{abstract}

Keywords: hard machining; combined procedure; gear wheels; operational allowance; surface quality; $3 D$ topography.

\section{INTRODUCTION}

The essence of the combined procedure is that workpiece machining can be finished in one machine-tool in a single clamping or even by the sequential application of more than one machining procedure [1]. This variant of operation concentration is widespread in hard machining, especially for joining two procedures: hard turning and grinding [2, 3]. It can be applied in machining external and internal cylindrical surfaces but the latter is more frequent. The reason for this is the fact that the bored gears of gearboxes are the components that are produced in the largest lot sizes in the automotive industry. Exact data are unknown but according to estimations the number of annually produced gearwheels is likely to be several billion [4]. It is obvious that the greatest profit can be earned in the production of such components by reducing the production time $[5,6,7]$. Developments aiming to increase productivity and improve quality technical are continuous in both procedure phases and in the machine tools applied in the procedure as well. In hard turning productivity has almost been doubled as the result of developments in wiper inserts. In grinding, the material removal rate has been significantly increased by the application of high-speed procedures $[8,9]$. In machine-tool development robotized service allows the parallel operation of more than one machine tool. However, there is a field that has been not sufficiently explored by research projects - the extent of grinding allowance in the second operation of the combined procedure [10]. 
Determination of this is based on empirical data; however, workshop data prove that grinding allowances that are significantly higher than the specified values are frequently applied. Therefore, the machining time of grinding may be increased significantly and for no particular reason.

\section{OPERATIONAL ALLOWANCES}

\subsection{Components of operational allowances}

The material thickness that forms the operational allowance is the sum of more than one layer of material [11]. These multiple layers allow the inherited errors and the errors of the operation to follow to be removed [12, 13]. That is, in order for error-free components to be machined, these two requirements have to be fulfilled:

- tool prints of the previous operation may not remain;

- there can be no patches on the surface of the component.

The three types of errors resulting from the previous operation (inherited errors) are:

- faulty surface layer;

- form and position errors;

- dimensional errors.

The three groups of errors occurring in the subsequent operation are:

- errors of base designation or base change;

- errors of clamping;

If machining is carried out on a traditional lathe and then with a grinding machine, the allowances have to be calculated and summarized separately for the two operations.

\subsection{Calculation of grinding allowance in combined procedure}

Calculation of the bore grinding allowance of the combined procedure is different from the traditional allowance calculation because due to the single clamping there is no base change $\left(Z_{s, b c}\right)$ or clamping $\left(Z_{s, c}\right)$ error. This means that only three remains from the five influencing factors.

\section{EXPERIMENTAL STUDY OF COMBINED PROCEDURE TO DETERMINE THE MINIMUM ALLOWANCE OF GRINDING}

\subsection{Experimental determination of minimum allowance}

In the case of the combined procedure the literature is quite poor in determining operational allowance. Since hard turning is 4 or 5 times more productive than grinding in bore machining, and better surface quality can be 
created, in the combined procedure it is enough to remove the bore grinding allowance that allows surface periodicity to be erased. Theoretically this layer thickness in hard turning is the created maximal surface roughness $\left(R_{\max }\right)$.

As the result of this procedure a random surface can be created that meets the running requirements (e.g. surfaces in relative motion; sealing surfaces, etc.) when turned topography is not suitable [14]. Removing the $R_{\max }$ extent of material thickness is only theoretically enough because beyond the advantages of single clamping, as indicated above, three factors still influence the extent of the necessary allowance. One way to determine this experimentally is by painting the surface; after that the various material layers are removed to the point that the machined surface is fully ground and contains no paint.

\subsection{Experimental determination of form error and its maximum value in hard turning}

The aim of the experimental program is the determination of form error (designated by $\mathrm{A})$ and maximum roughness $\left(R_{\max }\right)$. The experimental conditions of machining bores of gear wheels were the following:

Machine tool: EMAG VSC 400 DDS

Turning tool: CCGW 09T308 NC2, normal edge insert (CBN BNC200 60\%).

Table 1 - Workpiece and cutting data

\begin{tabular}{|c|c|c|}
\hline Wor & & Cutting data \\
\hline $\begin{array}{l}\text { Material: } \\
\text { 18CrNiMo7-6, case hardened } \\
\text { Hardness: 59-63HRC } \\
\text { Bore diameter: } 47 \mathrm{~mm} \\
\text { (nominal) } \\
\text { Bore length: } 20 \mathrm{~mm}\end{array}$ & $\sum$ & $\begin{array}{l}\text { Cutting speed: } \\
v_{c}=187.11 \mathrm{~m} / \mathrm{min} \\
\text { Depth-of-cut: } \\
a_{p}=0.05 \mathrm{~mm} \\
\text { Feed: } f=0.12 \mathrm{~mm}\end{array}$ \\
\hline
\end{tabular}

In the machining experiments bores of 10 gear wheels were hard turned. Surface roughness measurement was carried out by the application of the measuring equipment Altisurf 520 and then roundness was tested by the equipment Talysurf 365. Averages of 3-5 measured data of the hard turned surfaces are summarized in Table 2. In the last column the averages of the 10 results are also indicated.

Table 2 - Measured data of maximum roughness and form error

\begin{tabular}{|c|c|c|c|c|c|c|c|c|c|c|c|}
\hline & 1 & 2 & 3 & 4 & 5 & 6 & 7 & 8 & 9 & 10 & Average \\
\hline $\bar{R}_{\max }, \mu \mathrm{m}$ & 2.61 & 2.51 & 2.37 & 2.43 & 2.41 & 2.70 & 2.52 & 2.49 & 2.70 & 2.56 & 2.53 \\
\hline $\bar{A}, \mu \mathrm{m}$ & 8.21 & 8.07 & 7.80 & 6.11 & 8.04 & 7.23 & 5.95 & 6.34 & 5.86 & 6.01 & 6.97 \\
\hline
\end{tabular}




\subsection{Determination of maximal grinding allowance by painting method}

In the combined procedure it is important that the grinding allowance be no greater than necessary because material removal in hard turning is 4 to 5 times more productive. If the grinding allowance is greater than necessary after turning then the machining time of grinding increases significantly. This causes unnecessary extra time consumption when lot size is large. If, however, the allowance is too small, patches can remain on the surface of the bores. A special painting method was developed to analyze patches. The minimal grinding allowance is the value at which the surface will have just lost its patches and the tool prints of hard turning are totally removed. Using the painting method the patches can easily be noticed because they appear on the surface in red or blue.

\subsubsection{Conditions and cutting data of bore grinding}

Bore grinding was carried out after hard turning in the same clamping. The grinding spindle was clamped in the revolver head as a rotating tool. In the experiment five allowance levels were analyzed, each for five gear wheels, i.e. 25 operations were carried out. The allowances were $0.05 ; 0.04 ; 0.03 ; 0.02$; and $0.01 \mathrm{~mm}$. The working area of the machine tool and the position of grinding spindle are pictured in Fig. 1. Conditions and technological data of grinding are summarized in Table 3.

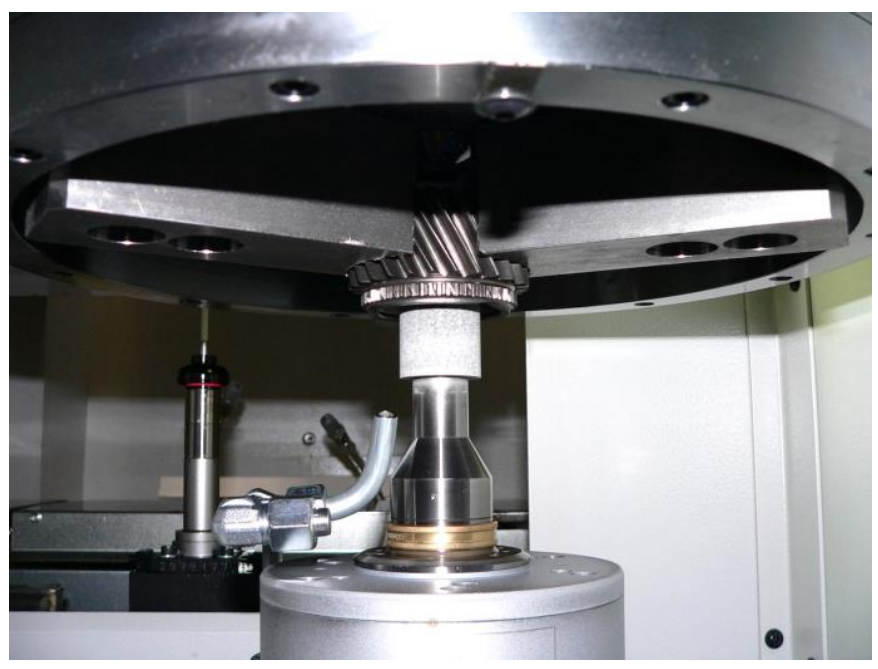

Figure 1 - Bore grinding spindle in working position 
Table 3 - Data of bore grinding

\begin{tabular}{|c|c|c|}
\hline & & \\
\hline $\begin{array}{l}\text { Dimensions: } \varnothing 36 \times 37 \times 13 \text {, } \\
\text { smooth grinding wheel; } \\
3 \text { AS80J8VET (Norton) }\end{array}$ & $\begin{array}{c}\text { Wheel velocity: } \\
v_{s}=40 \mathrm{~m} / \mathrm{s} \\
\text { Workpiece velocity: } \\
v_{w}=48 \mathrm{~m} / \mathrm{min} \\
\text { Velocity ratio: } q=50\end{array}$ & $\begin{array}{c}\text { Air grinding: } \\
v_{f, R, L M A X}=10 \mathrm{~mm} / \mathrm{min} \\
v_{f, R, L M I N}=2 \mathrm{~mm} / \mathrm{min} \\
\text { Roughing: } v_{f, R, N}=1 \mathrm{~mm} / \mathrm{min} \\
\text { Smoothing 1: } v_{f, R, S l}=0.6 \mathrm{~mm} / \mathrm{min} \\
\text { Smoothing } 2: v_{f, R, S 2}=0.1 \mathrm{~mm} / \mathrm{min}\end{array}$ \\
\hline \multicolumn{3}{|c|}{$\begin{array}{l}\text { - Stroke length of oscillation }: 2 \mathrm{~mm} \text {, its velocity: } v_{o}=200 \mathrm{~mm} / \mathrm{min} \text {; no. of strokes } \\
\text { - } n_{o}=3301 / \mathrm{min} \\
\text { - } \\
\text { - Spoolant and lubricant: Rhenus TS } 255 \% \text { solution } \\
\text { - Allowances (in diameter at the first five workpieces): roughing: } z_{N}=0.025 \\
\text { smoothing } 1: z_{S l}=0.010 ; \text { smoothing } 2: z_{S 2}=0.005\end{array}$} \\
\hline
\end{tabular}

\subsubsection{Qualification of allowances based on patch formation}

After painting the hard turned bores, bore grinding was carried out. After removing the various allowances, the clarity and patchy features of the surfaces were analyzed. The painting method proved unambiguously that there is no patch remained with allowances of $0.05,0.04$ or $0.03 \mathrm{~mm}$. The picture in Fig. 2 of the $0.03 \mathrm{~mm}$ allowance bores shows this; i.e. $0.03 \mathrm{~mm}$ allowance can be considered as a satisfactory allowance.

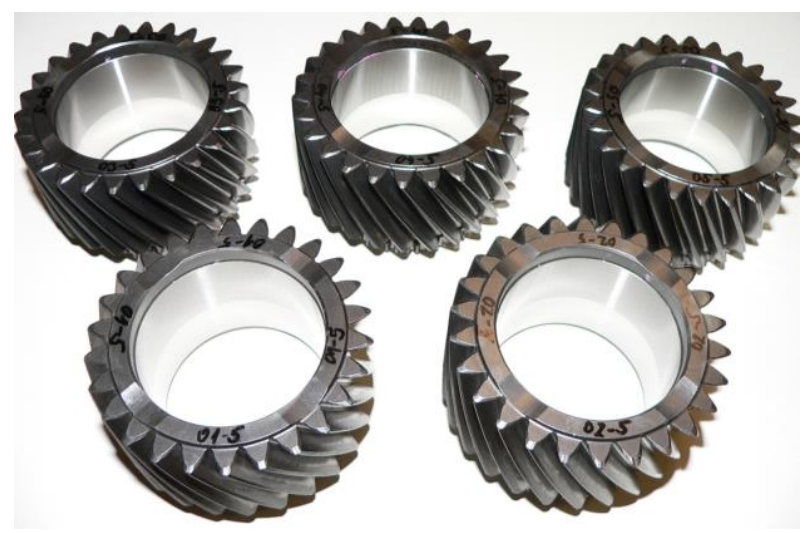

Figure 2 - None of the workpieces in the $0.03 \mathrm{~mm}$ allowance group include patches 
Roughness profiles of workpieces ground clean (without paint patches; $1^{\text {st }}, 2^{\text {nd }}$ and $3^{\text {rd }}$ groups) were analyzed and it was found that they have appropriate ground profiles in all cases. Tool prints of the previous operation cannot be noticed at all, they are completely ground (Fig. 3).
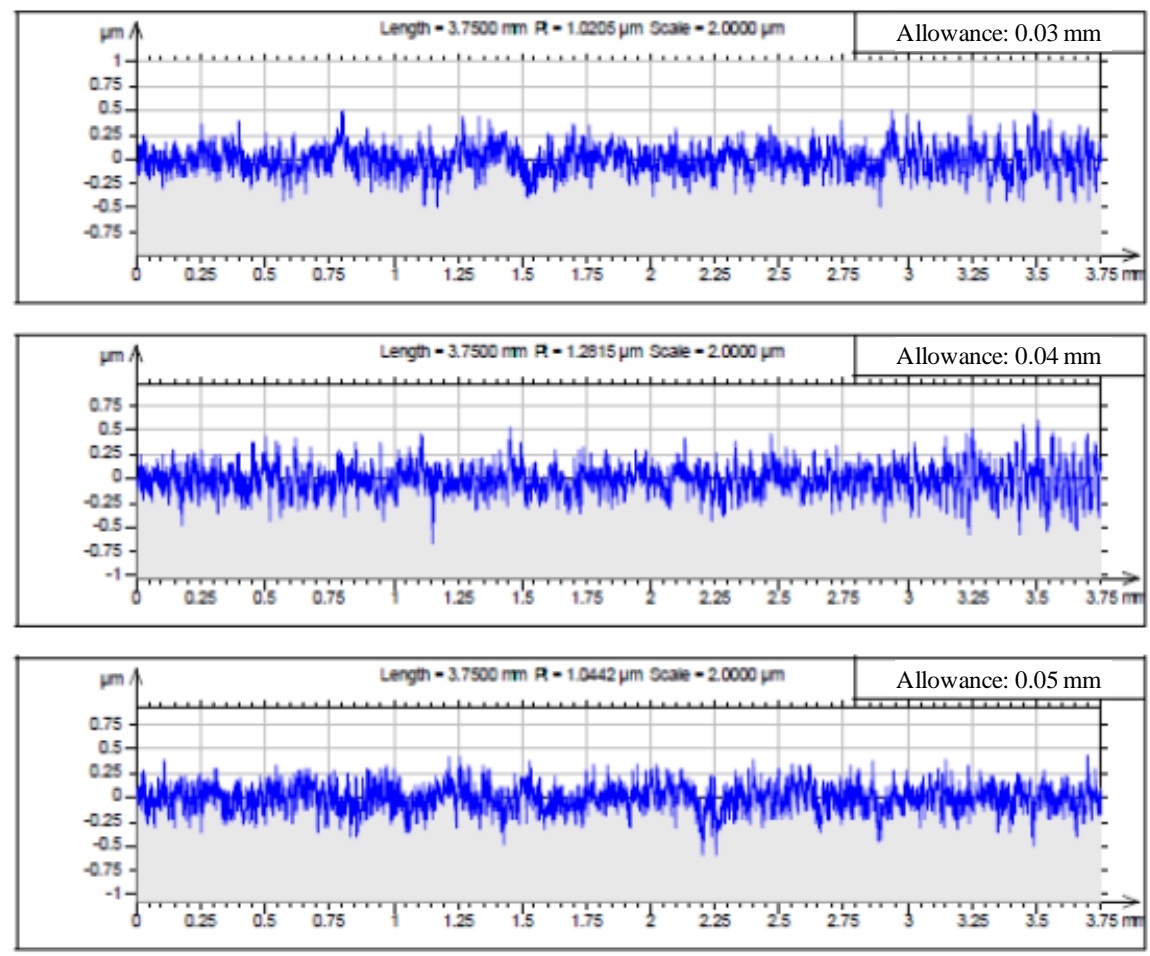

Figure 3 - Roughness profiles of workpieces without patches after grinding with allowances of $0.03 \mathrm{~mm}$ (top), $0.04 \mathrm{~mm}$ (middle), and $0.55 \mathrm{~mm}$ (bottom)

Inspecting the workpieces of the $4^{\text {th }}$ and $5^{\text {th }}$ allowance groups it was discovered that in case of the $0.02 \mathrm{~mm}$ allowance one of the five gear wheels contained patches and in case of the $0.01 \mathrm{~mm}$ allowance all the workpieces contained patches (Fig. 4). This means that 0.02 allowance was insufficient to completely grind the roughness profile remaining from the previous operation in all of the workpieces.

The roughness profile of a surface section including clear and also patchy parts was analyzed (Fig. 5). Two profile curves were analyzed for the $0.02 \mathrm{~mm}$ allowance workpiece on which a small patch can be noticed (Fig. 4a) with the 
patch included in the sampling area. Their locations were designated by A and B (Fig. 5). It can be observed that there is a place on the surface of the bore where the grinding wheel did not grind the surface.
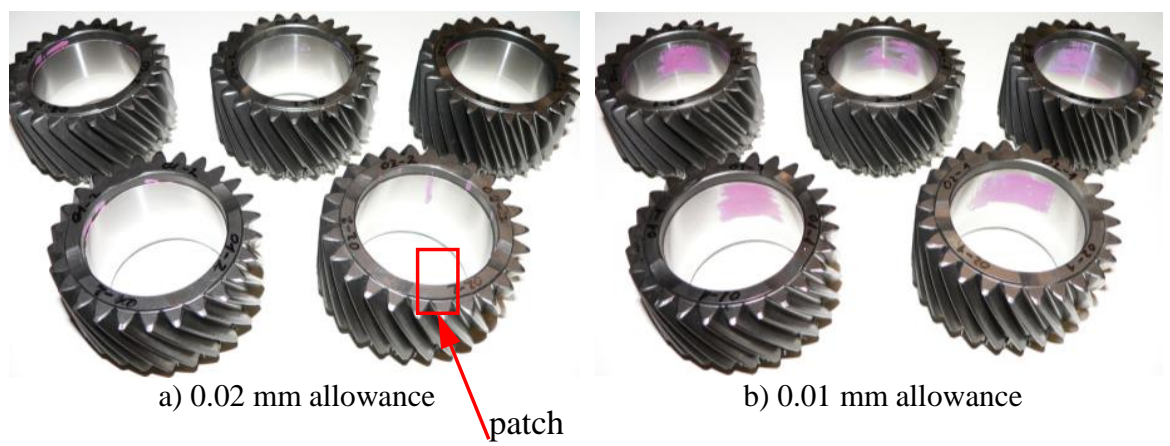

b) $0.01 \mathrm{~mm}$ allowance

Figure $4-$ In the $4^{\text {th }}$ allowance group (a) one workpiece and in the $5^{\text {th }}$ (b) all workpieces had one or more patches

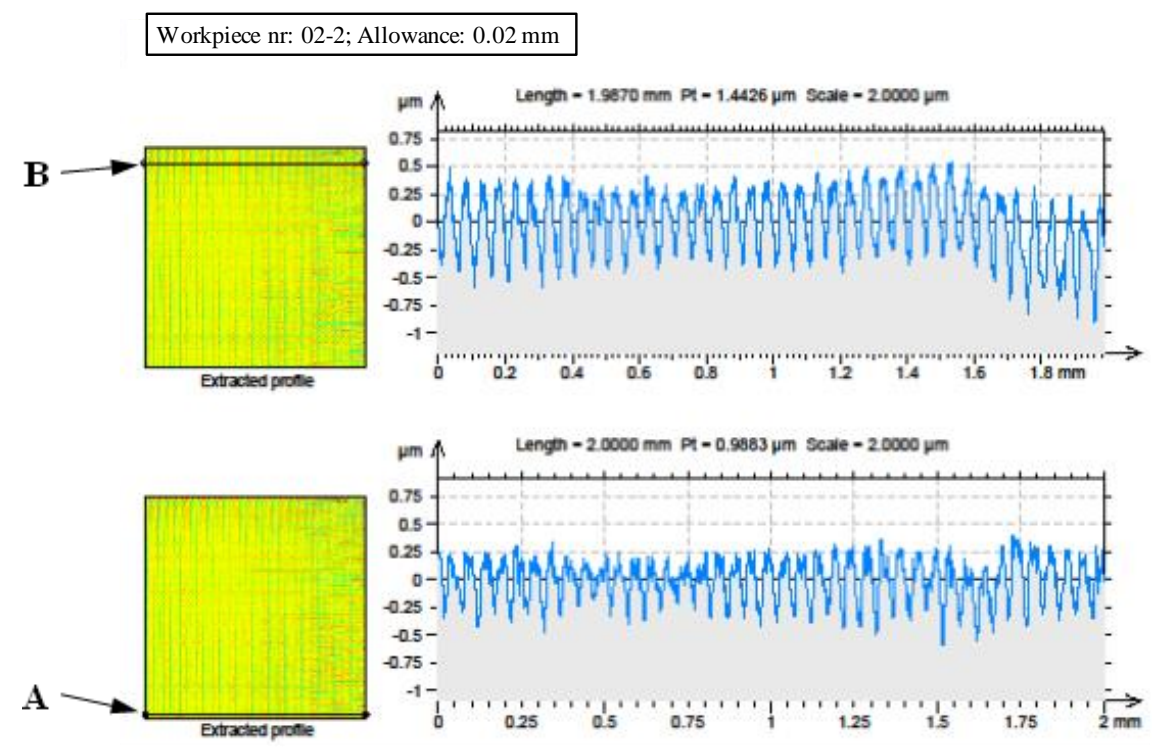

Figure 5 - Roughness profiles in the environment of the patchy area (0.02 $\mathrm{mm}$ allowance) 
Due to the insufficient allowance the grinding wheel only touched the roughness peaks or did not even reach them because of the form errors. It can be seen from the roughness profiles of sections A and B that they are non-ground profiles because the feed prints of turning as periodic formations can clearly be recognized in the profiles. The other characteristic is the significant asymmetry of the profile. Positive amplitudes are lower than negative, that is, the wheel ground a slight extent of material from the turned profile but by far not enough to eliminate the turned profile. From the comparison of sections A and B it can also be observed that the wheel removed more material from place A and less from place B. This fact is clearly expressed by the parameter $P_{t}$. From the profile of section B it is obvious that between the 1.7 and $2.0 \mathrm{~mm}$ section the wheel did not cut at all.

It can be stated that the colored patches on the surface and the roughness profiles are consistent with each other and the abnormal shapes of the roughness profiles is clear evidence that $0.02 \mathrm{~mm}$ allowance is not large enough to remove the tool prints of the previous operation. However, since the described problem was observed for only one workpiece from the five, reaching a $0.02 \mathrm{~mm}$ allowance is not an unrealistic goal if the factors influencing form errors are analyzed more profoundly and if it is possible to make corrections (e.g. reduce the clamping force or apply other clamping equipment).

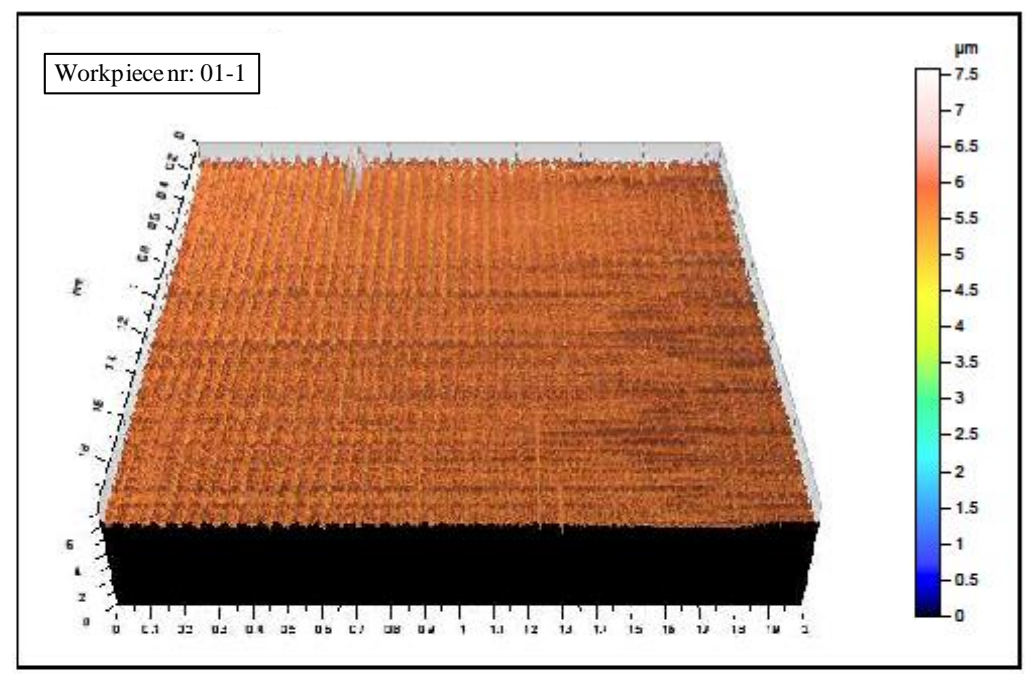

Figure $6-3 \mathrm{D}$ topography on surface near a patch: inhomogeneous topography (random: right bottom part; periodic: left top part) 
Finally, the patchy workpieces of the $5^{\text {th }}$ allowance group were also analyzed. The phenomena analyzed in the previous group were perceived more frequently. Irregularities of roughness profiles can also be experienced in the 3D topographies. An example is shown in Fig. 6. It can be observed that there are two types of topography in the sampling area. In one area, which is characterized by higher allowance, random topography was created and on another the allowance was lower, thus periodic topography remained there. It is obvious that this type of "mixed" topography is the consequence of inappropriate allowance, which is unacceptable.

\section{SUMMARY}

In the experiment the extent of necessary and sufficient allowance was determined by a special painting method in machining experiments. Assuming no white layer was formed on the surface, the main conclusion is that, the experimental method can provide useful information in the technology planning phase of machining. Another important result is that current grinding allowances can be reduced. Therefore, machining time can be saved while producing identical surface quality. Based on our experimental data a $0.03 \mathrm{~mm}$ finishing grinding allowance (measured in diameter) is necessary and sufficient for the combined machining of bores of gearbox wheels if no white layer has formed in the previous hard turning operation. Industrial experience shows that when case-hardened gearwheel materials are machined in well-chosen cutting circumstances, white-layer formation is unlikely. The results of the experiments demonstrated that a further decrease in the $0.03 \mathrm{~mm}$ allowance may be possible and even a $0.02 \mathrm{~mm}$ allowance value may be obtainable, but further research is needed to determine the necessary technological conditions.

\section{ACKNOWLEDGEMENTS}

Project No. NKFI-125117 has been implemented with the support provided from the National Research, Development and Innovation Fund of Hungary, financed under the K_17 funding scheme. The described study was carried out as part of the EFOP-3.6.1-16-00011 "Younger and Renewing University - Innovative Knowledge City - institutional development of the University of Miskolc aiming at intelligent specialisation" project implemented in the framework of the Szechenyi 2020 program. Both sources of funding are gratefully acknowledged.

References: 1. Lutjens, P.: Grosse Vorteile durch Kombinationsbearbeitung, Werkstatt und Betrieb 9, 2008, pp.114-119. 2. Kundrak, J., Deszpoth, I., Molnar, V.: Comparative Examination for the Machining of Hard Surfaces, International Conference on Innovative Technologies: IN-TECH 2012, Rijeka, 2012, pp.305-309. 5 p. 3. Kundrak, J., Molnar, V. Deszpoth, I.: Comparative Analysis of Machining Procedures, Machines 6(2), 2018, Paper 13, p.6. 4. Kundrak, J.: Alternative Machining Procedures of Hardened Steels, Manufacturing Technology 11, 2011, pp.32-39. 5. Klocke, F., 
Brinksmeier, E., Weinert, K.: Capability Profile of Hard Cutting and Grinding Processes, CIRP Annals Manufacturing Technology 54 (2), 2005, pp.557-580. 6. Kundrák, J., Gyáni, K., Deszpoth, I.: The Efficiency of Combined Machinings, Rezanie i Instrumenty v Tekhnologicheskih Sistemah 81, 2012, pp.140-151. 7. Kundrak, J., Varga, G., Deszpoth, I., Molnar, V.: Some Aspects of the Hard Machining of Bore Holes, Applied Mechanics and Materials 309, 2013, pp.126-132. 8. Knиefermann, M.M.W., McKeown, P.A.: A Model for Surface Roughness in Ultraprecision Hard Turning, CIRP Annals, 53, 2004pp.99-102. 9. Kundrak, J., Molnar, V., Deszpoth, I.: Analysis of Machining Time and material Removal Performance as Factors Influencing Efficiency and Profitability, Lecture Notes in Mechanical Engineering, 2018, pp.268-279. 10. Tonshoff, H.K., Arendt, C., Ben Amor, R.: Cutting of Hardened Steel, CIRP Annals - Manufacturing Technology, 49(2), 2000, pp.547-566. 11. Dornfeld, D., Lee, D.E.: Precision Manufacturing, Springer, 2008p.41. 12. Косилова, А.Г., Мещеряков, Р.К.: Справочник технолога-машиностроителя, Москва Машиностроение, 1985, p.19. 13. Khonsari, M.M.: Applied Tribology, Wiley, 2008, p65. 14 Waikar, R.A., Guo, Y.B.: A Comprehensive Characterization of 3D Surface Topography Induced by Hard Turning versus Grinding, Journal of Materials Processing Technology 197, 2008, pp.189-199.

\title{
Янош Кундрак, Іштван Деспот, Віктор Мольнар, Мішкольц, Угорщина \\ ПІДВИЩЕННЯ ПРОДУКТИВНОСТІ КОМБІНОВАНОГО МЕТОДУ ОБРОБКИ ЗА РАХУНОК ЗМЕНШЕННЯ ПРИПУСКУ НА ШЛІФУВАННЯ
}

\begin{abstract}
Анотація. При шліфуванні швидкість видалення матеріалу значно збільшується завдяки застосуванню високошвидкісних методів. У верстатобудуванні робототехнічне обслуговування дозволяе здійснювати паралельну роботу більш ніж одного верстата. Однак існує сфера, яка недостатньо досліджена дослідницькими проектами - величина припуску на шліфування під час другої операції комбінованого методу. Визначення иього параметру базується на емпіричних даних, однак, дані експериментів свідчать про те, щео часто застосовуються припуски на шліфуванняння, які значно перевищують вказані значення. Тому час обробки шліфуванням може бути значно збільшений $i$ без особливих причин. У разі комбінованого методу, даних в літературі у визначенні операчійного посібника, досить мало. Оскільки точіння на токарному верстаті в 4 або 5 разів продуктивніше, ніж шліфування при обробці отворів, і можна досягти кращої якості поверхні, в комбінованому методі досить видалити припуск на шліфування отвору, щчо дозволяє звести до нуля періодичність поверхні. В цих дослідженнях були проведені експерименти для визначення мінімального ступеню допустимого припуску матеріалу, щьо шліфується на оброблюваних деталях типу «корпус» комбінованим методом. Ступінь прийнятного або неприйнятного припуску визначали методом "розпису». Після шліфування проводили вимірювання 2D шорсткісті, округлості i $3 D$ топографію. Було встановлено, що припуск 0,03 мм в отворах коліс коробки передач автомобілів є задовільним для отримання необхідного рівня рельєфу при застосуванні комбінованої обробки і при відсутності білого шару в процесі обробки. Це є досить значним висновком, оскільки звичайні припуски 0,05 мм або вище (y багатьох випадках значно вищі) можуть бути зменшені до 0,33 мм, а час обробки иліфуванням отворів може бути зменшено пропориійно до цүієі величини.
\end{abstract}

Ключові слова: жорстка обробка; комбінована процедура; зубчасті колеса; експлуатачійні норми; якість поверхні; 3D топографія. 